\title{
Anthropogenic Vegetation in the River Valley Amalat
}

\author{
Marina Tsyrenova*, Evgenia Pyzhikova and Elena Vasilyeva \\ Buryat State University, 24 «A» Smolina st., Ulan-Ude city, Russia
}

\begin{abstract}
The article presents the results of a research study of anthropogenic affects of gold mining on forest landscapes in Northern Transbaikalia, Russia and processes of natural reclamation of vegetation cover of the disturbed areas. The study area is located northwest of the Maliy Amalat River, which flows along the Vitim Plateau; in the floodplains of its two tributaries the Aunik River and the Bagdarin River. It is an area where a large number of alluvial gold deposits have been discovered. Some of these deposits are currently being developed, some have already been explored, and some have been abandoned. The authors consider the current state of vegetation cover in a key area of the Amalat River basin, near villages of Malovsky and Bagdarin. The problem of natural resources development and conservation is becoming extremely important for the area under study because open-pit gold mining methods that are used here drastically change the environment and affect water, land and forest resources.
\end{abstract}

The study area is located northwest of the Malyi Amalat River, which flows along the Vitim Plateau, at the confluence of its two tributaries the Aunik and Bagdarinka Rivers, where a large number of alluvial gold deposits is located (Fig.)

Some of these deposits have already been explored, some are currently being developed, and some have been abandoned. In the past centuries, dredge mining and underground mining were two of the most widely used methods. Currently, the work is mostly carried out on shallow alluvial placer gold deposits using hydro-monitor units. The work is done by small-scale miners, the so called artels, as well as prospectors.

Extensive development of the gold-mining industry over the period of two hundred years resulted in transformation of large territories of the region under study, and led to degradation and landscape pollution. Open-pit gold mining methods drastically change the environment and affect water, land and forest resources. Thus, the problem of natural resources development and conservation is becoming extremely important for this area with continental taiga permafrost landscapes.

Decades of extensive industrial development of the region have led to serious ecological crises. Currently, at least $70 \%$ of agricultural soil of the region is transformed, and about 100.000 hectares of land are completely destroyed. Gold mining results in changes of the main components of ecosystems - topography, hydrological regime of rivers, groundwater

\footnotetext{
* Corresponding author: tsyrenova2000@mail.ru
} 
flow, soil composition and vegetation cover. Anthropogenic landscapes appear in areas of destroyed ground, and their lithogenic basis is totally changed as a result of mining equipment usage

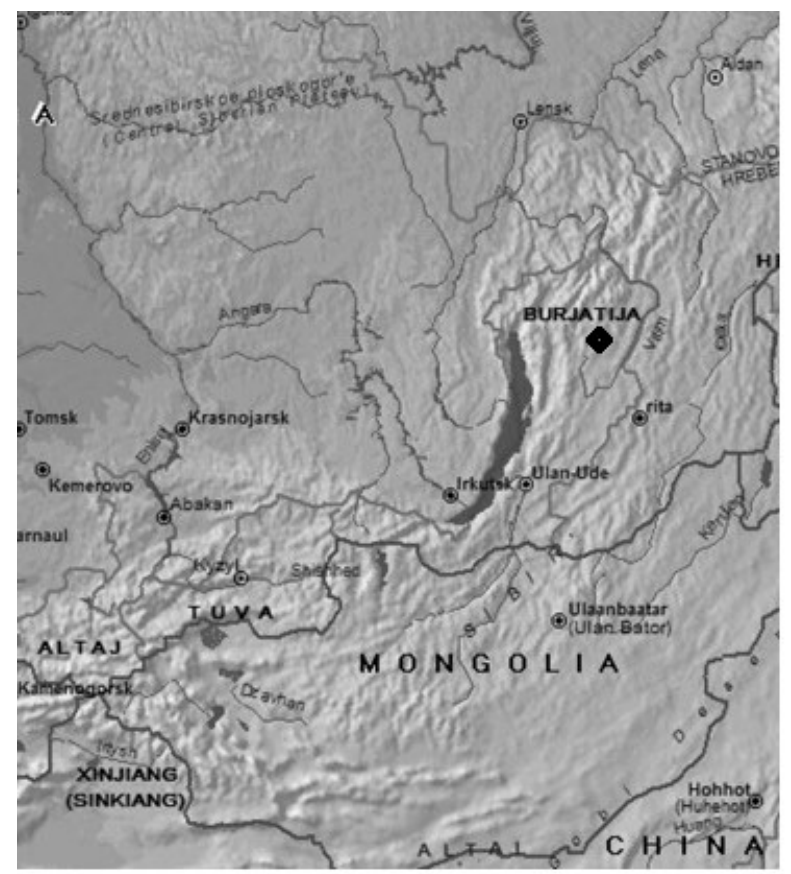

Fig. The study area.

The research site is located in the continental taiga sector consisting mostly of lightcolored coniferous trees. It is characterized by the dominance of Larix gmelini with lichens, Rhododendron dauricum, Betula fruticosa and a well-developed moss layer [1]. Forests cover the upper part of the positive landforms (hills, buttes, etc.), rivers and lakes natural levees, and river valleys; they are characterized by poorness of species composition. The basic forest species are Larix gmelini (80\%), Betula pendula (16\%); rarely forests can be comprised of Populus tremula, P. suaveolens, Pinus sylvestris. Shrubland variety of species is not very diverse; mostly they include Betula fruticosa s. str. with Ledum palustre and Vaccinium uliginosum, Betula fruticosa with Carex, Betula fruticosa with mixed grass and Betula fruticosa. They are formed at the bottoms of canyons and narrow river valleys. Less frequently one may see Salix sp. communities along rivers and lakeshores. Meadow vegetation is widespread and is adapted to various lowlands: river floodplains, lake basins, erosion gullies, etc.

The anthropogenic landscapes vegetation is characterized by specific character of economic activity in the region. Total disturbance of valleys landscapes was observed on the areas of long-time use of the dredge equipment (The Aunik and The Bagdarinka Rivers Valleys). Partial disturbance was registered in the areas where alluvial placer deposits came into exploitation not long ago or were mined with the help of industrial equipment (the Gulinga River Valley). Natural reclamation of soil and vegetation components is slow and depends on the degree of disturbance and physico-chemical properties of the soil. Mine tailings soil components are considered to be potentially productive for natural reclamation; they contain up to $3 \%$ of humus, not less than $10 \%$ of clay, up to $20 \%$ of fine-grained deposits. 
44 geobotanical descriptions were studied on dumps in river valleys: Anik, Bagdarinka and Ghoulinga (the basin of the Malyi Amalat river).

As a result of processing the obtained materials, 2 groups were identified:

- young dumps with an initial stage of overgrowth (2-3 years or more);

- old dumps (more than 30 years) with varying degrees of overgrowing.

At the first stage of self-pollution of dumps, the vegetation cover is fragmented.

Newly made big mine tailings and their slopes are completely devoid of vegetation due to the strong soil compaction by heavy machinery, as a result seeds can't root and are blown away by the wind. Such vegetation as Chamaenerion angustifolium, Alopecurus aequalis, Draba nemorosa, Plantago depressa dominate mine tailings produced a year ago (the Bagdarinka River Valley). It is possible to find seedlings of Artemisia vulgaris, A. commutata there too. On the western slopes of young dumps (more than 3 years) and on the northern slopes of older dumps (more than 6 years), forests from Chosenia arbutifolia were described . For them tailings are similar to their natural habitat - sandy-gravel alluvium on the floodplains of mountain rivers. Chosenia arbutifolia communities are pioneer communities, the dominants are Chosenia arbutifolia, Chamaenerion angustifolium, Potentilla anserina, P. supina ssp. paradoxa, Ptarmica alpina, Poa angustifolia, Erigeron acris, Calamagrostis langsdorfii

Separately, the vegetation of technical foundation pit was studied. Vegetation is represented by diverse groups of wetland and aquatic species., the dominants are Halerpestes salsuginosa, Bekmannia syzigachne, Puccinellia tenuiflora, Equisetum hyemale, Scirpus hippolyti, Typha laxmannii, Epilobium palustre, Carex rostrata, Agrostis divaricatissima.

This vegetation (of young dumps) is the pioneer communities on the studied dumps. Then they are transformed into meadow and typical willow communities.

Mine tailings (Gulinga river) produced 30 years ago are characterized by willow trees vegetation Salix rorida, $S$. viminalis, $S$. schwerinii, the dominants are Pedicularis sceptrumcarolinum, Salix kochiana, Gentianopsis barbata, Arctopoa subfastigiata, Carex schmidtii. At some spots it is possible to see Larix gmelinii seedlings.

Reclaimed tailings may be found in the low parts of the Bagdarinka River where mining reclamation was carried out more than 30 years ago. Within this period natural ecosystems have been reclaimed and now are represented by light-colored coniferous forests comprised by Larix gmelinii, the dominants are Geranium sibiricum, Geum aleppicum, Potentilla tanacetifolia, Pulsatilla multifida, Astragalus adsurgens, Sedum aizoon.

Further more detailed studies will allow to reveal the regularities of plant communities formation, syngenetic successions and the strategies of land invasion by individual species in the process of anthropogenic mine tailing reclamation.

\section{References}

1. E.M. Pyzhikova , M.G. Tsyrenova, S.D. Shirapova, Natural and technical sciences, 1 (127) (2019) 